\title{
The Irrational Beliefs and the Psychological Symptoms of The Sexual Abuse Victims
}

Nilufer Kocturk', Filiz Bilge ${ }^{2}$

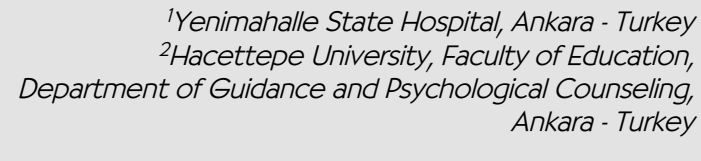

'Yenimahalle State Hospital, Ankara - Turkey

${ }^{2}$ Hacettepe University, Faculty of Education,

Ankara - Turkey

\section{ABSTRACT}

The irrational beliefs and the psychological symptoms of the sexual abuse victims Objective: Sexual revictimization (SR) is one of the important results of childhood sexual abuse, and an important issue that should be investigated and prevented. Evaluating irrational beliefs and the psychological symptoms of sexually revictimized adolescents would be useful in determination of the victims and in preventing the SR. This descriptive study examined irrational beliefs and psychological symptoms of the adolescents who have been exposed to SR, one-time sexual abuse (SA) and those who have not been exposed to SA.

Methods: Participants were 210 adolescent girls who are aged between 15-18. The data was collected via the Brief Symptom Inventory and the Irrational Belief Scale-Adolescent Form, and a one-way ANOVA was utilized for data analysis.

Results: No significant difference has been determined in the mean irrational belief scores of the adolescents with respect to sexual abuse victimization. However, it was found that the psychological symptoms-such as depression, negative self-perception, somatization, hostility-of the adolescents exposed to SR are higher than the comparison group and the ones who have been exposed to one-time SA. The anxiety symptom scores of the adolescents who have been exposed to SR was significantly higher than the adolescents in the comparison group, and was similar with with the adolescents in SA group. It was determined that the group who have been exposed to one time SA, have higher mean scores of anxiety, depression, negative self-perception and somatization than the comparison group.

Conclusion: Different psychological problems can be seen in adolescents who have been exposed to SR and one-time SA. It is believed that taking into account of such differences may be helpful in the process of the treatment of victims.

Keywords: Adolescent, child, irrational beliefs, psychological symptoms, sexual revictimization

\section{ÖZET}

Cinsel istismar mağdurlarının psikolojik belirtileri ve akılcı olmayan inançları

Amaç: Tekrarlanan cinsel istismar (TCi), çocukluk çağı cinsel istismarın (Ci) önemli sonuçlarından biri olup, araştııııması ve önlenmesi gereken konuların başında gelmektedir. TCi mağdurlarının psikolojik belirti düzeylerinin ve akılcı olmayan inançlarının belirlenmesi bu sorunun önlenmesine ve tedavi edilmesine katkı sağlayacaktır. Bu amaçla, çalışmada TCl'ye maruz kalan, bir kez Cl'ye maruz kalan ve Ci'ye maruz kalmamış ergenlerin psikolojik belirti düzeylerinin ve akılcı olmayan inançlarının anlamlı farklar gösterip göstermediğinin belirlenmesi hedeflenmiştir.

Yöntem: Araştırmanın çalışma grubunu 210 kız ergen oluşturmaktadır. Veri toplamak amacıyla Kısa Semptom Envanteri ve Akılcı Olmayan İnançlar Ölçeği kullanılmıştır. Verilerin analizinde tek yönlü varyans analizinden yararlanılmıştır.

Bulgular: Araştırmada Cl'ye maruz kalma durumuna göre ergenlerin akılcı olmayan inanç puan ortalamaları arasındaki farkların istatistiksel olarak anlamlı olmadığı sonucuna varııııștır. Buna karşın, TCìye maruz kalan ergenlerin depresyon, olumsuz benlik, somatizasyon ve hostilite puanlarının karşıllaştırma grubundan ve bir kez Cl'ye maruz kalanların puan ortalamalarından daha yüksek olduğu; kaygı puan ortalamalarının da sadece karşılaştırma grubunun kaygı puan ortalamasından daha yüksek olduğu, bir kez Cliye maruz kalan ergenlerin puan ortalamaları ile arasında anlamlı bir fark olmadığı belirlenmiştir. Bir kez Cl'ye maruz kalan grubun ise kaygı, depresyon, olumsuz benlik ve somatizasyon puan ortalamalarının karşılaştırma grubunun puan ortalamasından daha yüksek olduğu saptanmıştır.

Sonuç: TClye ve Cìye maruz kalan ergenlerde farklı psikolojik sorunlar görülebilmektedir. Mağdurların tedavi sürecinde bu tür farkllıkların gözetilmesinin yararlı olabileceği düşünülmektedir.

Anahtar kelimeler: Ergen, çocuk, akılcı olmayan inançlar, psikolojik belirti, tekrarlanan cinsel istismar
How to cite this article: Kocturk N, Bilge F. The irrational beliefs and the psychological symptoms of the sexual abuse victims. Dusunen Adam The Journal of Psychiatry and Neurological Sciences 2017;30:113-123.

https://doi.org/10.5350/DAJPN2017300205

Address reprint requests to / Yazışma adresi Nilufer Kocturk,

Yenimahalle State Hospital,

Batikent/Ankara, Turkey

Phone / Telefon: +90-312-587-2000

E-mail address / Elektronik posta adresi: nilkeser@hacettepe.edu.tr

Date of receipt / Geliş tarihi: January 6, 2017 / 6 Ocak 2017

Date of the first revision letter / ilk düzeltme öneri tarihi:

January 10, 2017 / 10 Ocak 2017

Date of acceptance / Kabul tarihi: January 24, 2017 / 24 Ocak 2017

This article is part of PhD thesis of the first author. 


\section{INTRODUCTION}

C hildhood sexual abuse (SA), one of the traumatic events, is a serious problem that may be seen worldwide (1). Sexual revictimization (SR), although it has various definitions in literature (2), is the SA experienced in adolescence or adulthood for individuals who were exposed to SA in the childhood (3). The prevalence of SA is reported between $8.5-71 \%(1,4-7)$ in the literature; and the rate of SR as $10-69 \%$ (8). In a study, SA was found to be $8.5 \%$, and $45.6 \%$ of those who were exposed to SA during childhood were also exposed to SA during adolescence (6). According to Humphrey and White (9), the odds for SA at adolescence increases 1.8 fold if they had been exposed to SA before 14 years old. A prevalence study in the United States suggests that 769,000 female adolescents are SR victims and 154,000 of them have post-traumatic stress disorder (PTSD) (10). Despite the high rates of both $\mathrm{SA}$ and $\mathrm{SR}$ in the literature, it is thought that these ratios do not reflect the facts due to various reasons such as the legal differences in the definition of SA and the lack of reporting $(5,11)$. Along with similar problems, the proportion of SA in Turkey is not clearly known due to the lack of extensive research on the prevalence of SA and differences among sample groups. However, the prevalence of SA was found as $13.4 \%$ according to a study conducted on female high school (12). No research has been reported $S R$ rates. In most studies it appears that multiple SAs (exposure to more than one SA by the same person) are given as SR rates (13). In this study, SR was considered as being exposed to SA by a different abuser during adolescence when having been exposed to SA in the childhood.

In the literature, it is reported that there is a significant relationship between childhood SA and SR during adolescence $(6,8,9,14,15)$ and adulthood $(7,9,16)$, and psychiatric disorders increase SR risk $(8,15,17)$. One study found that girls had $27.9 \%$ more SR risk than boys, about $1 / 3$ of SR victims had mental health problems, and those with mental health problems had a $28.7 \%$ increased risk of SR (17). In another study, the SR rate of female adolescents was found to be $52.7 \%$, and
$19.4 \%$ of them had been diagnosed with PTSD in the last six months and $27.8 \%$ of them were experiencing lifetime PTSD symptoms. When compared to the SA victim group, SR adolescents were found to be more likely to meet PTSD criteria in the last six months and lifetime (10). In a screening study, SR was found to be associated with high levels of stress and certain psychiatric disorders and SR victims were reported to have more cognitive and behavioral problems such as emotional regulation, addiction, and more embarrassment, weakness, and self-blame (8). Similarly, another study points out that stress scores, which are the sum of depression and anxiety scores, are important for SR in both children and adolescents (18).

In the post-SA period, several factors take effect in the adaptation of victims or in their encountering psychiatric problems; and irrational beliefs may be one of these factors (19). Irrational beliefs are unreasonable, constant, unchanging, and unrealistic thoughts (20). According to the Rational Emotive Behavior Theory, there are irrational beliefs in the mentally unhealthy individuals that include "should" expressions, low frustration tolerance, and self-humiliation (21). Life events do not determine emotions, but rational or irrational beliefs determine emotions, and behaviors associated with life events (21). Research data on irrational beliefs that play a role in the development of psychopathology, supports this view $(22,23)$. In a study conducted with pregnant adolescents $(n=204)$, the SA rate was determined as $1 / 4$, and it was determined that the perceived stress level of the SA victims was higher and irrational beliefs predicted stress level and negative emotions (22).

In a study of 57 victims of physical and sexual abuse, cognitive variables such as negative beliefs about themselves and the environment, inconsistent control strategies (avoidance/security seeking), and interpretation of maltreatment behaviors were found as significant predictors of PTSD severity (23). Similarly, in a study conducted with 43 adult SA victims, it was found that impaired beliefs about safety, trust, self-confidence, or intimacy were associated with post-traumatic symptoms (24). In a 
study comparing the victims of physical and sexual abuse with and without PTSD symptoms and nonvictimized adults, it was found that the victims who had PTSD symptoms had more negative beliefs, and there was a relation between post-abuse negative beliefs and occurrence of PTSD (25). In this study, it was stated that the victims who had no PTSD statement had more positive pre-SA beliefs than the comparison group, concluding that positive beliefs may be a preventive factor in the development of PTSD. The results are concluded as: trauma experienced with SA may lead to changes on the basic beliefs of victims, nonfunctional basic beliefs can be formed or supported, and this leads to nonfunctional beliefs. Nonfunctional beliefs may also be associated with adaptation problems in emotions (depression, anxiety, guilt, anger) and behaviors (interpersonal problems, sexual dysfunction, repeated victimization, avoidance) (26).

As noted above, many studies have been carried out on the mental problems and irrational beliefs of SR victims outside Turkey. However, it is obvious that research on SR is mostly performed with adults and the number of studies performed on adolescents is limited. Besides, we could not reach any study comparing psychiatric symptoms and irrational beliefs of three adolescent groups, exposed to SR, exposed to SA just one time and not exposed to SA. Another aspect is, due to the fact that cultural factors are taken into consideration and there is no research on SR victims in Turkey, the issue needs to be evaluated in terms of Turkey. In a systematic review that evaluated studies about childhood sexual abuse in Turkey in the last 12 years, it is emphasized that there is a need for SR-related research (27). As a result, in order to prevent SA victims from re-victimization and to realize the necessary interventions, it is very important to determine their problems. At the same time, it is believed that this will save time for mental health professionals during treatment of SA victims and increase the effectiveness of the treatment. For all these reasons, in this study it was aimed to determine whether irrational beliefs and psychological symptom levels showed significant differences in SR, SA and non-SA adolescent groups. For this purpose, the researchers seeked the answer of the question: "Are there any significant difference between psychological symptom and irrational belief average scores of SR, SA and non-SA adolescents?"

\section{METHOD}

This is a comparative descriptive study, using the appropriate sampling method (28) as the sampling method. Since a significant difference in irrational beliefs and psychological symptom levels between the three groups in the study was sought, this study is of the "comperative relational research scan model" (29).

In the study, SR was regarded as being exposed to SA again in the adolescence period of a child who was exposed to SA before adolescence (13 years), and only adolescents reporting contact type SA were included in the study. After forensic interviews, the SR and the SA groups were formed according to the declaration of the victim.

\section{Study Sample}

A total of 210 adolescent girls at 15 to 18 years of age participated in the research. Of the all participants $33.3 \%(n=70)$ were exposed to SR, 33.3\% ( $n=70)$ were exposed to SA and $33.3 \%(n=70)$ were not exposed to SA. The mean age of all children in the sample is $\bar{x}=15.96, \mathrm{SD}=0.81$. Mean age of $\mathrm{SR}$ group is $\bar{x}=15.93, \mathrm{SD}=0.97$; mean age of comparison group is $\bar{x}=16, \mathrm{SD}=0.83$; mean age of the SA group is $\bar{x}=15.96$, $\mathrm{SD}=0.82$.

The number of SA events for victims exposed to SR varies between $2-30$. Of the all victims $65.7 \%$ $(n=46)$ experienced twice SA, 14.3\% $(n=10)$ experienced three times SA, $12.9 \%(n=9)$ experienced 4 times, $1.4 \%(n=1)$ experienced 6 times, $2.9 \%(n=2)$ experienced 10 times, $1.4 \%(n=1)$ experienced 15 times, and $1.4 \%(n=1)$ experienced SA 30 times. The mean number of SA of victims with $\mathrm{SR}$ is $\bar{x}=3.34$ $(\mathrm{SD}=4.38)$. 
The age of first incident of SR victims was between 7 and 12 years old. The victims of both SA and SR groups experienced sexual abuse the last time, at ages between 13 and 18 years. The time from the incident to disclosure in the victims' last SA varies from 24 hours to 4 years. The victims in both groups stated that they have not been treated for the last one year.

\section{Measures}

Brief Symptom Inventory (BSI): In order to measure the psychological symptoms of adolescents in the study, Brief Symptom Inventory (BSI), which is adapted to Turkish by Sahin and Durak (30) was used. BSI is an abbreviated form of the 90-item Symptom Checklist known as SCL-90, which was developed by Derogatis (1992) (31). BSI is a five-point Likert-type scale consisting of 53 items. Examples of scale items include "difficulty falling asleep" and "feelings of guilt". BSI also scores on three types of global indices: Global Severity Index - GSI, Positive Symptoms Total - PST and Positive Symptoms Distress Index. Scores that can be taken from the scale range from 0 to 212 . The higher scores on the scale and subscales indicate the higher frequency of the psychological symptoms of the individual.

Structure validity and reliability studies of BSI have been carried out. Factor analysis for construct validity of BSI revealed that the scale consisted of five dimensions as "anxiety", "depression", "negative selfperception", "somatization" and "hostility" and the total variance was found to be $32 \%$ (31). Scales used for the validity of similar scales were the Social Comparison Scale (SCS), Submit Scale (SS), Stress Vulnerability Scale (SVS), Offer Loneliness Scale (OLS), Beck Depression Inventory (BDI) and UCLA Loneliness Scale. Correlation coefficients calculated between the scores obtained from BSI and the scores obtained from each scale were as follows: with SCS $r=-0.14$ and $r=-0.34$; with SS $r=0.16$ and $r=0.42$; with SVS $R=0.24$ and $r=0.36$; with OLS $r=0.34$ and $r=-0.57$; with BDI $r=0.34$ and $r=0.70$; with the UCLA Loneliness Scale, $r=0.13$ and $r=0.36$.
The Cronbach's alpha coefficients obtained from the total scores of BSI were found between 0.93 and 0.96 (30). In addition, the alpha reliability coefficient was 0.87 for the anxiety dimension, 0.88 for the depression dimension, 0.87 for the negative self perception dimension, 0.75 for the somatization dimension and 0.76 for the hostility dimension. The Cronbach alpha coefficients calculated for this study are 0.85 for the somatization dimension, 0.91 for the negative self-perception dimension, 0.94 for the depression dimension, 0.90 for the anxiety dimension and 0.75 for the hostility dimension.

\section{Irrational Belief Scale -Adolescent Form (IBS-A):}

In order to measure the irrational beliefs of adolescents in the study, Irrational Belief Scale -Adolescent Form (IBS-A), adapted by Turkum, et al. (32) were used. IBS-A is a five-point Likert-type scale consisting of 16 items. The lowest score of the scale is 16 , the highest score is 80. The higher scores on the scale indicates that the level of irrational beliefs of the individual is high. "Misfortune always finds me", "I can not stand the absence of my loved ones" are examples of the items on the scale.

Structure validity and reliability studies of IBS-A have been carried out. Factor analysis for construct validity of the scale revealed that the scale consists of one dimension the total explained variance $51.3 \%$ (32). Dysfunctional Attitude Scale and Automatic Thoughts Scale were taken as measures for the validity of similar scales. The Pearson Product-Moment Correlation Coefficients for IBS-A was calculated as 0.47 with the Dysfunctional Attitude Scale and 0.85 ( $p>0.05$ ) with the Automatic Thoughts Scale (32).

The item total correlation, two half-test correlations and the internal consistency coefficient were calculated for the reliability study of the IBS-A. The item-total correlation coefficients ranged from 0.20 to 0.41 . The two-half correlation coefficient was 0.69 and the internal consistency coefficient of all the scales was 0.70 . These findings were interpreted as indicative of the reliability of the scale (29). The Cronbach alpha coefficient calculated in this study is 0.70 . 


\section{Procedure}

This study was conducted at the Ankara Child Monitoring Center, where forensic interviews were held for SA victims. After the ethics committee approval obtained, two groups of 70 female adolescents who were exposed to a single SA and multiple SAs and whose ages were between 15-18 years were selected by appropriate sampling method at the Ankara Child Monitoring Center between September 2013 and June 2014. As a result of the forensic interviews at the Ankara Children's Monitoring Center, the participants were informed by the informed consent forms and accepted to take a part in the study on a volunteer basis. Scales were applied after the interviews. The comparison group consisted of 70 female adolescents between 15 - 18 years of age who admitted to the pediatric outpatient clinic of the hospital where the center was located and reported in the individual interview that they have not been exposed to SA and that there was no chronic disease. Informed consents were also obtained from the adolescents in the comparison group before the scales were applied. The data collection process was finalized in June of 2014.

\section{Statistical Analysis}

SPSS 21.0 was used in the statistical analysis of the data obtained in the study. First, it was checked whether the collected data met the assumptions for parametric tests. One-way analysis of variance (One Way ANOVA) was used to test sub-problems. In multiple comparison tests, the homogeneity of variances was analyzed by the Levene $F$ test and if the variances were homogeneous, Tukey test; if not Dunnett C test was utilized (33). However, the magnitude of effects (eta squared), which indicates how effective the independent variable is on the dependent variable, has also been examined. The effect size was evaluated as "small level effect" for $0.01 \leq \eta^{2}<0.06$, "medium level effect" for $0.06 \leq \eta^{2}<0.14$ and "large level effect" for $\eta^{2} \geq 0.14$ (34).

\section{RESULTS}

First, the psychological symptoms of adolescents in terms of their exposure to SA were examined. Psychological manifestations covered in the research were; anxiety, depression, negative self-perception, somatization and hostility. Table 1 shows that the mean scores of anxiety, depression, negative selfperception, somatization, and hostility scores of female adolescents participating in the research were different with regard to their exposure to SA. When values are examined; it is seen that the highest mean scores belong the adolescents exposed to SR and the lowest mean scores belong to the comparison group.

When ANOVA results are examined (Table 1), at least one of the differences between the adolescents' mean scores of anxiety $\left(\mathrm{F}_{2: 207}=13.88 ; \mathrm{p}<0.001\right)$, depression $\left(\mathrm{F}_{2 ; 207}=17.02 ; \mathrm{p}<0.001\right)$, negative selfperception $\left(\mathrm{F}_{2: 207}=18.16 ; \mathrm{p}<0.001\right)$, somatization $\left(\mathrm{F}_{2 ; 207}=13.71 ; \mathrm{p}<0.001\right)$, hostility $\left(\mathrm{F}_{2 ; 207}=18.303\right.$; $\mathrm{p}<0.001)$ and BSI-GSI $\left(\mathrm{F}_{2 ; 207}=19.323 ; \mathrm{p}<0.001\right)$ was found to be significant. Since the Levene test was not homogeneous for the variables anxiety $\left(\mathrm{F}_{2 ; 207}=3.202\right.$; $\mathrm{p}<0.05)$ and somatization $\left(\mathrm{F}_{2: 207}=4.434 ; \mathrm{p}<0.05\right)$, the Dunnett $C$ binary comparison test was used to compare group differences on these scales. Since Levene statistic indicated that group variances were homogeneous for depression $\left(\mathrm{F}_{2: 207}=1.208 ; \mathrm{p}>0.05\right)$, negative self-perception $\left(\mathrm{F}_{2 ; 207}=1.854 ; \mathrm{p}>0.05\right)$, hostility $\left(\mathrm{F}_{2.207}=0.109 ; \mathrm{p}>0.05\right)$, and BSIGSI $\left(\mathrm{F}_{2: 207}=1.885 ; \mathrm{p}>0.05\right)$, the Tukey binary comparison test was used. The results of the Dunnett $C$ and Tukey binary comparison test are given in Table 2 .

According to the results given in Table 2 , the mean anxiety, depression, negative self-perception, somatization, hostility and BSI-GSI scores of the adolescents exposed to SR are higher than the mean scores of the comparison group and SA group. On the other hand, no significant difference was found between the mean anxiety scores of the adolescents exposed to SR and the adolescents who were once exposed to SA. When Eta squared value is examined, it is seen that there is medium level effect with $\eta^{2}=0.12$. When the mean depression, negative 
Table 1: Descriptive values and variance analysis results of adolescents' BSI subscales and irrational belief scores according to SA exposure status

\begin{tabular}{|c|c|c|c|c|c|c|c|}
\hline Scale & Groups & $\mathbf{n}$ & $\bar{x}$ & SD & $\mathbf{F}$ & Levene & Eta Squared $\left(\eta^{2}\right)$ \\
\hline \multirow[t]{4}{*}{ BSI-Anxiety } & Comparison group & 70 & 15.07 & 10.52 & $13.877^{* * *}$ & $3.202^{*}$ & 0.12 \\
\hline & Once SA & 70 & 21.54 & 11.94 & & & \\
\hline & $\mathrm{SR}$ & 70 & 25.87 & 13.92 & & & \\
\hline & Total & 210 & 20.83 & 12.94 & & & \\
\hline \multirow[t]{4}{*}{ BSI-Depression } & Comparison group & 70 & 17.73 & 12.04 & $17.017^{* * *}$ & 1.208 & 0.14 \\
\hline & Once SA & 70 & 24.73 & 13.6 & & & \\
\hline & SR & 70 & 30.5 & 13.24 & & & \\
\hline & Total & 210 & 24.32 & 13.93 & & & \\
\hline BSI-Negative & Comparison group & 70 & 12.79 & 10.32 & $18.163^{* * *}$ & 1.854 & 0.15 \\
\hline \multirow[t]{3}{*}{ Self-Perception } & Once SA & 70 & 18.27 & 12.04 & & & \\
\hline & SR & 70 & 24.5 & 12.08 & & & \\
\hline & Total & 210 & 18.52 & 12.42 & & & \\
\hline \multirow[t]{4}{*}{ BSI-Somatization } & Comparison group & 70 & 8.94 & 6.77 & $13.713^{* * *}$ & $4.434^{*}$ & 0.12 \\
\hline & Once SA & 70 & 12.56 & 8.26 & & & \\
\hline & SR & 70 & 16.04 & 8.89 & & & \\
\hline & Total & 210 & 12.51 & 8.49 & & & \\
\hline \multirow[t]{4}{*}{ BSI-Hostility } & Comparison group & 70 & 10.33 & 5.58 & $18.303^{* * *}$ & 0.109 & 0.15 \\
\hline & Once SA & 70 & 12.54 & 5.71 & & & \\
\hline & SR & 70 & 16.06 & 5.66 & & & \\
\hline & Total & 210 & 12.98 & 6.1 & & & \\
\hline \multirow[t]{4}{*}{ BSI-GSI } & Comparison group & 70 & 1.22 & 0.77 & $19.323^{* * *}$ & 1.885 & 0.16 \\
\hline & Once SA & 70 & 1.69 & 0.89 & & & \\
\hline & SR & 70 & 2.13 & 0.92 & & & \\
\hline & Total & 210 & 1.68 & 0.94 & & & \\
\hline \multirow[t]{4}{*}{ Irrational Beliefs } & Comparison group & 70 & 62.41 & 7.31 & 0.019 & 1.823 & 0.001 \\
\hline & Once SA & 70 & 62.60 & 9.92 & & & \\
\hline & SR & 70 & 62.30 & 9.95 & & & \\
\hline & Total & 210 & 62.44 & 9.10 & & & \\
\hline
\end{tabular}

BSI: Brief Symptom Inventory, BSI-GSI: Brief Symptom Inventory Global Severity Index, Once SA: Exposed to Sexual Abuse Once Only, SR: Sexual Revictimization, n: Number of Subjects, $\bar{x}$ : Mean, SD: Standard Deviation, ${ }^{*} \mathrm{p}<0.05 ;{ }^{* *} \mathrm{p}<0.01 ;{ }^{* * *} \mathrm{p}<0.001$

self-perception, somatization and BSI-GSI scores were examined, it was determined that adolescents who were once exposed to SA had also higher mean scores of depression, negative self-perception, somatization, and BSI-RCI than the scores compared to the control group. When Eta squared value was examined, it was determined that there is large effect for depression $\eta^{2}=0.14$, negative self-perception $\eta^{2}=0.15$ and BSI-GSI $\eta^{2}=0.16$ and medium effect for somatization $\eta^{2}=0.12$. When the hostility variable was considered, there was no significant difference between the mean hostility score of the adolescents who were exposed to SA once and the control group. When Eta squared value is examined, it is seen that it has a large effect with $\eta^{2}=0.15$.

Another variable that is evaluated in this study is irrational beliefs. As shown in Table 1, according to the exposure to $\mathrm{SA}$, the mean scores of the unreasonable beliefs between groups are different. When the values are examined, it is seen that the highest mean scores belong to the adolescents who are exposed to SA once, and the lowest mean score to the adolescents who are exposed to SR. When ANOVA results were examined, the mean irrational beliefs scores were similar between groups $\left(\mathrm{F}_{2: 207}=1.823 ; \mathrm{p}>0.05\right)$. In the study, it was found that the differences between the mean irrational beliefs scores according to the exposure to SA were not statistically significant. When the Eta squared value is examined, a very small effect with $\eta^{2}=0.001$ suggests that exposure to $\mathrm{SA}$ is not a significant influence on the unreasonable belief scores of adolescents. 
Table 2: Differences between the mean scores of adolescents' BSI subscales according to their exposure to SA

\begin{tabular}{|c|c|c|c|c|}
\hline \multirow{2}{*}{$\begin{array}{l}\text { Dependent Variable } \\
\text { Anxiety }\end{array}$} & \multicolumn{2}{|l|}{ SA Exposure } & \multirow{2}{*}{$\begin{array}{c}\text { Difference Between Means } \\
-6.47143\end{array}$} & \multirow{2}{*}{$\frac{\mathbf{p}}{0.006}$} \\
\hline & Comparison group & Once SA & & \\
\hline & & SR & -10.80000 & $<0.001$ \\
\hline & Once SA & Comparison group & 6.47143 & 0.006 \\
\hline & & SR & -4.32857 & 0.093 \\
\hline & SR & Comparison group & 10.80000 & $<0.001$ \\
\hline & & Once SA & 4.32857 & 0.093 \\
\hline \multirow[t]{6}{*}{ Depression } & Comparison group & Once SA & -7.00000 & 0.005 \\
\hline & & SR & -12.77143 & $<0.001$ \\
\hline & Once SA & Comparison group & 7.00000 & 0.005 \\
\hline & & SR & -5.77143 & 0.025 \\
\hline & SR & Comparison group & 12.77143 & $<0.001$ \\
\hline & & Once SA & 5.77143 & 0.025 \\
\hline \multirow[t]{6}{*}{ Negative Self-Perception } & Comparison group & Once SA & -5.48571 & 0.014 \\
\hline & & SR & -11.71429 & $<0.001$ \\
\hline & Once SA & Comparison group & 5.48571 & 0.014 \\
\hline & & SR & -6.22857 & 0.004 \\
\hline & SR & Comparison group & 11.71429 & $<0.001$ \\
\hline & & Once SA & 6.22857 & 0.004 \\
\hline \multirow[t]{6}{*}{ Somatization } & Comparison group & Once SA & -3.61429 & 0.022 \\
\hline & & SR & -7.10000 & $<0.001$ \\
\hline & Once SA & Comparison group & 3.61429 & 0.022 \\
\hline & & SR & -3.48571 & 0.029 \\
\hline & SR & Comparison group & 7.10000 & $<0.001$ \\
\hline & & Once SA & 3.48571 & 0.029 \\
\hline \multirow[t]{6}{*}{ Hostility } & Comparison group & Once SA & -2.21429 & 0.055 \\
\hline & & SR & -5.72857 & $<0.001$ \\
\hline & Once SA & Comparison group & 2.21429 & 0.055 \\
\hline & & SR & -3.51429 & $<0.001$ \\
\hline & SR & Comparison group & 5.72857 & $<0.001$ \\
\hline & & Once SA & 3.51429 & 0.001 \\
\hline \multirow[t]{6}{*}{ Global Severity Index } & Comparison group & Once SA & -0.46765 & 0.004 \\
\hline & & SR & -0.90782 & $<0.001$ \\
\hline & Once SA & Comparison group & 0.46765 & 0.004 \\
\hline & & SR & -0.44016 & 0.008 \\
\hline & SR & Comparison group & 0.90782 & $<0.001$ \\
\hline & & Once SA & 0.44016 & 0.008 \\
\hline
\end{tabular}

Once SA: Exposed to Sexual Abuse Only Once, SR: Sexual Revictimization

\section{DISCUSSION}

In this study, psychological symptoms and irrational belief levels were examined in adolescents who were exposed to SR, who were exposed to SA once and who were not exposed to SA. Anxiety, depression, negative self-perception, somatization, hostility, and BSI-GSI variables were evaluated in context of psychological symptoms. According to the results of the study, the mean scores of irrational belief survey was not statistically significant between study groups. On the other hand, it was determined that the adolescents who were exposed to SR had higher mean scores of depression, negative self-perception, somatization, hostility, and BSI-GSI than the adolescents who were exposed to SA once; the mean anxiety score of the SR group was higher than the control group. The mean anxiety scores were similar between SA and SR groups. It was determined that the mean scores of anxiety, depression, negative self-perception, somatization and BSI-GSI of the group of adolescents who were exposed to SA were higher than the control group. 
Our findings about the higher levels of psychological symptoms of SA victims are generally consistent with the literature. Similar to our study, it is emphasized in other studies that SA victims can exhibit anxiety, depression, negative self-perception and somatization symptoms, and the risk of developing psychopathology may increase with the severity and the number of abuses $(8,15,35,36)$. In a study it was found that those exposed to SA both during childhood and adulthood exhibited more somatic symptoms than those exposed to SA only in childhood; and those exposed to SA only in childhood, as well as the ones exposed to SR, suffered from somatization, depression, anxiety, hostility and PTSDrelated symptoms were found to be more frequent than those who were not exposed to SA (35). According to the Traumagenic Dynamics Model that was developed by Finkelhor and Browne (37) SA may lead to anxiety, depression, somatization, low selfperception, problems in interpersonal relationships, and repeated victimizations.

In this study, all of the symptom scores of the SR group-other than anxiety-were different from the SA group. Most severe symptoms of depression, negative self-perception, somatization, and BSI-GSI were seen in the SR group. These findings suggest that higher psychopathology scores might be related with multiple SA exposure or the charecteristics of abuse might have resulted from multiple SA exposure or from the characteristics of the abuse, and that these may be a distinctive factor for the SR and the SA victims. However, in order to arrive at a definite conclusion there is a need for causal and longitudinal studies, when considering that factors specific to abuse and abuser also influence the development of psychopathology (38). On the other hand, the presence of more psychological symptoms in the SR group suggests that this may be a factor directly or indirectly leading to susceptibility to subsequent SA. It is more likely that a victim with a high psychological symptom level becomes a target of abusers by acquiring negative peers. For this reason, while psychological symptoms are thought to be a result of abuse, at the same time, it can serve as a means for repetitive victimizations. In addition, in the ecological model by Grauerholz (39), which tries to explain repeated victimizations, it is emphasized that repeated victimization is affected by several aspects of multiple factors such as, past history of the victim (eg, SA associated with violence, running away from home, isolation), settings of the abuse (e.g., lack of ability to resist), society (e.g., poor family support) and cultural factors (e.g., blaming the victim). These characteristics, which depict the victims of SR, might be the cause of similarities and differences between the SR group and other groups in this study. For instance, the SR group experienced a process where they were able to evaluate the reaction of their families and the society after the first SA incident. On the other hand, in the SA group, the majority of the SA reports are new and they have not been able to evaluate their family and community reactions as the SR group. However, there is a need for causal studies in which the relevant variables are controlled in order to arrive at a definite view in this respect.

In this study, it was determined that-in contrast to what we expected- the differences between the mean scores of unreasoning belief levels between the three groups were not statistically significant. We have not found any study in the literature which investigated adolescents that were exposed to SR, and to SA once only and those that have not been exposed to SA. On the other hand, unlike the methodology and findings of this study, it was determined that non-functional or irrational beliefs of SA victims were found to be predictive of the stressors, negative emotions and severity of PTSD $(22,23)$. In a study of adult victims exhibiting and not exhibiting PTSD symptoms, it was found that victims without PTSD symptoms experienced more positive beliefs whereas the victims exhibiting PTSD symptoms had more negative thoughts after the abuse (25). This shows the importance of having positive thoughts before and after abuse. Although many studies emphasized the negative impact of SA on victims, in our study there was no significant difference between groups in terms of unreasonable beliefs. The reason for this inconsistency between our findings and the literature 
may be related with the sample characteristics, the cultural differences or the reliability of the scales that used in this study. The reliability value of the Irrational Beliefs Scale used in the study was calculated as 0.70 and the scale does not assess abusespecific irrational beliefs. For this reason, there is a need for new research that assesses the irrational beliefs specific to abuse.

There are some limitations to this study. First, the lack of male victims in the sample group is one of them. There is a need for new studies in which psychological symptoms and irrational beliefs of male victims are examined and gender differences are assessed on these variables. Second, this study is the first study in Turkey that examines the psychological symptoms and irrational belief levels of adolescents who have been exposed to SA and who have not. Therefore, future research are needed to assess the generalizability of our findings. Third, all types SA by physical contact-from mild (eg, touching the genital organ) to severe (eg. sexual intercourse) were included in this study and psychological symptoms and irrational beliefs were not compared according to the severity of SA. Considering that the type of SA is a factor that may affect the level of trauma, psychological symptoms and irrational beliefs can be evaluated according to the severity level of SA and trauma in future studies. Fourth, the fact that only the victim's statement is collected in this study is another limitation. Finally, since the Irrational Beliefs Scale does not assess irrational beliefs specific to abuse, a scale examining the abuse-specific beliefs and attributions of SA victims can be developed.

In conclusion, different psychological problems can be seen in adolescents exposed to SR and SA. It is believed that it may be useful to observe such differences in the treatment process in order to reduce the psychological symptoms of the victims and indirectly to help prevent their exposure to SA. On the other hand, proffessionals working with children, especially school psychological counselors, can follow the female adolescents with psychological symptoms indicated in the study in terms of exposure to SA, and they can make interventions that will facilitate the disclosure of victims' SAs.

\begin{tabular}{|l|l|}
\hline Contribution Categories & Name of Author \\
\hline Development of study idea & N.K., F.B. \\
\hline Methodological design of the study & N.K., F.B. \\
\hline Data acquisition and process & N.K. \\
\hline Data analysis and interpretation & N.K., F.B. \\
\hline Literature review & N.K., F.B. \\
\hline Manuscript writing & N.K., F.B. \\
\hline Manuscript review and revisation & N.K., F.B. \\
\hline
\end{tabular}

Conflict of Interest: Authors declared no conflict of interest.

Financial Disclosure: Authors declared no financial support.

\section{REFERENCES}

1. Stoltenborgh M, Van Ijzendoorn MH, Euser EM, BakermansKranenburg MJ. A global perspective on child sexual abuse: meta-analysis of prevalence around the world. Child Maltreat 2011; 16:79-101. [CrossRef]

2. DePrince AP, Chu AT, Labus J, Shirk SR, Potter C. Testing two approaches to revictimization prevention among adolescent girls in the child welfare system. J Adolesc Health 2015; 56(Suppl.2):33-39. [CrossRef]

3. Arata CM. Child sexual abuse and sexual revictimization. Clin Psychol (New York) 2002; 9:135-164. [CrossRef]

4. Everill J, Waller G. Disclosure of sexual abuse and psychological adjustment in female undergraduates. Child Abuse Negl 1995; 19:93-100. [CrossRef]

5. Finkelhor D, Shattuck A, Turner HA, Hamby SL. The lifetime prevalence of child sexual abuse and sexual assault assessed in late adolescence. J Adolesc Health 2014; 55:329-333. [CrossRef]

6. Miron LR, Orcutt HK. Pathways from childhood abuse to prospective revictimization: depression, sex to reduce negative affect, and forecasted sexual behavior. Child Abuse Negl 2014; 38:1848-1859. [CrossRef] 
7. Thoresen S, Myhre M, Wentzel-Larsen T, Aakvaag HF, Hjemdal OK. Violence against children, later victimisation, and mental health: a cross-sectional study of the general Norwegian population. Eur J Psychotraumatol 2015; 6:26259. [CrossRef]

8. Classen CC, Palesh OG, Aggarwal R. Sexual revictimization a review of the empirical literature. Trauma Violence Abuse 2005; 6:103-129. [CrossRef]

9. Humphrey JA, White JW. Women's vulnerability to sexual assault from adolescence to young adulthood. J Adolesc Health 2000; 27:419-424. [CrossRef]

10. Walsh K, Danielson CK, McCauley JL, Saunders BE, Kilpatrick DG, Resnick HS. National prevalence of posttraumatic stress disorder among sexually revictimized adolescent, college, and adult household-residing women. Arch Gen Psychiatry 2012; 69:935-942. [CrossRef]

11. Wager NM. Understanding children's non-disclosure of child sexual assault: implications for assisting parents and teachers to become effective guardians. Safer Communities 2015; 14:16-26.

\section{[CrossRef]}

12. Alikasifoglu M, Erginoz E, Ercan $O$, Albayrak-Kaymak D, Uysal $\bigcirc$, Ilter $\bigcirc$. Sexual abuse among female high school students in Istanbul, Turkey. Child Abuse Negl 2006; 30:247255. [CrossRef]

13. Bulut GC. Investigaton of the factors and the serotonin gene polymorphism, which play role in the development of psychopathology in adolescent sexual abuse cases [Unpublished specialization thesis]. Marmara Universitesi; Istanbul, 2013. (Turkish).

14. D’Abreu LC, Krahé B. Vulnerability to sexual victimization in female and male college students in Brazil: cross-sectional and prospective evidence. Arch Sex Behav 2016; 45:1101-1115. [CrossRef]

15. Krahé B, Berger A. Gendered pathways from child sexual abuse to sexual aggression victimization and perpetration in adolescence and young adulthood. Child Abuse Negl 2017; 63:261-272. [CrossRef]

16. Ports KA, Ford DC, Merrick MT. Adverse childhood experiences and sexual victimization in adulthood. Child Abuse Negl 2016; 51:313-322. [CrossRef]

17. Pittenger SL. Predicting sexual revictimization in childhood and adolescence: A prospective examination using ecological systems theory [PhD dissertation]. Lincoln: University of Nebraska; 2016.

18. Pittenger SL, Schreier A, Meidlinger K, Pogue JK, Theimer K, Flood MF, Hansen DJ. Psychological distress and revictimization risk in youth victims of sexual abuse. J Interpers Violence 2016 Jul 7. pii: 0886260516658755. [Epub ahead of print] [CrossRef]
19. Valle LA, Silovsky JF. Attributions and adjustment following child sexual and physical abuse. Child Maltreat 2002; 7:9-25. [CrossRef]

20. Hamarta E, Arslan C, Saygın Y, Özyeşil Z. Benlik saygısı ve akılcı olmayan inançlar bakımından üniversite öğrencilerinin stresle başa çı kma yaklaşımlarının analizi. Değerler Eğitimi Dergisi 2009; 7:25-42.

21. Murdock NC. Theories of counseling and psychotherapy. Akkoyun F (Translation ed.) 2. Edition, Ankara: Nobel Scholar Publishing, 2012, 273-313. (Turkish)

22. Walsh K, Basu A, Monk C. The role of sexual abuse and dysfunctional attitudes in perceived stress and negative mood in pregnant adolescents: an ecological momentary assessment study. J Pediatr Adolesc Gynecol 2015; 28:327-332. [CrossRef]

23. Dunmore E, Clark DM, Ehlers A. A prospective investigation of the role of cognitive factors in persistent posttraumatic stress disorder (PTSD) after physical or sexual assault. Behav Res Ther 2001; 39:1063-1084. [CrossRef]

24. Wenninger K, Ehlers A. Dysfunctional cognitions and adult psychological functioning in child sexual abuse survivors. J Trauma Stress 1998; 11:281-300. [CrossRef]

25. Ali T, Dunmore E, Clark D, Ehlers A. The role of negative beliefs in posttraumatic stress disorder: A comparison of assault victims and non victims. Behav Cogn Psychother 2002; 30:249-257. [CrossRef]

26. Rieckert J, Möller AT. Rational-emotive behavior therapy in the treatment of adult victims of childhood sexual abuse. J Ration Emot Cogn Behav Ther 2000; 18:87-101. [CrossRef]

27. Uslu RI, Kapci EG. Sexual exploitation and sexual abuse of children in Turkey: Systematic review of the last 12 years studies. Ankara: Alp Offset Printing House; 2014. (Turkish)

28. Teddlie C, Yu F. Mixed methods sampling: a typology with examples. J Mix Methods Res 2007; 1:77-100. [CrossRef]

29. Karasar N. Scientific Research Method, $21^{\text {st }}$ ed. Ankara: Nobel Publishing; 2010. (Turkish)

30. Sahin NH, Durak A. Brief Symptom Invetory-BSI: Adaptation for Turkish Youth Turk gencleri icin uyarlanmasi. Turk Psikoloji Dergisi 1994; 9:44-56. (Turkish)

31. Sahin NH, Durak-Batigun A, Ugurtas S. The validity, reliability and factor structure of the brief symptom inventory (BSI). Turk Psikiyatri Derg 2002;13:125-135. (Turkish)

32. Turkum AS, Balkaya A, Karaca A. The Adaptation of the irrational beliefs scale to high school students: validity and reliability studies. Turkish Psychological Counseling and Guidance Journal 2005; 3:77-85. (Turkish) 
33. Buyukozturk S. Data analyses for social sciences. Ankara: Pegem Academy Publishing; 2011. (Turkish)

34. Cohen J. Statistical power analysis for the behavioral sciences. $2^{\text {nd }}$. ed. Hillsdale, NJ: Lawrence Erlbaum Associates, Publishers; 1988.

35. Messman-Moore TL, Long PJ, Siegfried NJ. The revictimization of child sexual abuse survivors: an examination of the adjustment of college women with child sexual abuse, adult sexual assault, and adult physical abuse. Child Maltreat 2000; 5:18-27. [CrossRef]

36. Putnam FW. Ten-year research update review: child sexual abuse. J Am Acad Child Adolesc Psychiatry 2003; 42:269-278.

\section{[CrossRef]}

37. Finkelhor D, Brown A. The traumatic impact of child sexual abuse: a conceptualization. Am J Orthopsychiatry 1985; 55:530541. [CrossRef]

38. Bendixen M, Muus KM, Schei B. The impact of child sexual abuse-a study of a random sample of Norwegian students. Child Abuse Negl 1994; 18:837-847. [CrossRef]

39. Grauerholz L. An ecological approach to understanding sexual revictimization: linking personal, interpersonal, and sociocultural factors and processes. Child Maltreat 2000; 5:5-17. [CrossRef] 
Copyright of Dusunen Adam: Journal of Psychiatry \& Neurological Sciences is the property of Yerkuere Tantim ve Yayincilik A.S. and its content may not be copied or emailed to multiple sites or posted to a listserv without the copyright holder's express written permission. However, users may print, download, or email articles for individual use. 